\title{
Chapter 10 \\ The Significance of the Media Didactics \\ Course for Masters of Vocational Education
}

\author{
Mamatair Joldoshov and Ainura Bekbolsunova
}

\subsection{Introduction}

The timeliness for introducing media didactics in the system of higher education by integrating of the media educational technologies in training of future professionals is determined by coming into existence a fundamentally new concept in vocational training, including media education strategies that aim at forming media education culture as an essential component of the professional culture of a future specialist. This means media didactics of higher educational institutions, as well as the new and advanced educational technologies.

The analysis of application of the media and innovative technologies in teaching and learning process for masters of vocational education in the context of technical and humanitarian higher educational institutions of the Kyrgyz Republic and the Republic of Kazakhstan has led us to the development of the study guide Media Didactics.

It is commonly known that the new multimedia technologies resulted in creation of new forms of knowledge management and knowledge arrangement. According to the new principles, training means independence, cooperation, interactivity, and creativity. The course Media Didactics contributes to introducing new forms of learning, creating the new role of a teacher, active introducing of the new technolo-

\footnotetext{
M. Joldoshov $(\bowtie)$

Engineering Pedagogy Department, Kyrgyz State Technical University named after

I. Razzakov, Bishkek, Kyrgyzstan

e-mail: jktair@mail.ru
}

\author{
A. Bekbolsunova $(\bowtie)$ \\ Department Fine and Applied Art, Kyrgyz State Technical University named after \\ I. Razzakov, Bishkek, Kyrgyzstan \\ e-mail: ainura1412@mail.ru
}


gies in the learning and teaching process, and providing free access to media resources.

The introduction of the course Media Didactics for masters of engineering is an important factor in modernization of education. At present, in the context of modern vocational education, the multimedia pertains to the most dynamically developing and promising technology.

The development of scientific and technological progress and introduction of modern computer and telecommunication hardware, capable to store, to process, and to provide various types of information; introduction and development of modern multimedia systems; and methodical innovations have changed drastically the training of masters in universities, as well as approaches of the learning activities at all levels of the educational system.

The traditional didactics objectives are to describe and to explain the training process and its implementation, to develop more modern teaching and learning processes, and to organize an educational process, new training systems, and new learning technologies. The principles of general didactics, which in their unity objectively reflect the most important regularities of the learning process, play a defining role in selecting content, methods, and forms of education.

Each academic discipline has its own characteristic features and regularities, as well as requires special methods and organizational modes of study. Private didactics or teaching methods deal with these issues. According to the researchers, all private methods are pedagogical disciplines based on the same fundamentals as the general didactics discloses. Thus, the general didactics is a theoretical basis for all private methods. Private methods and general didactics are developing in close unity.

\subsection{The Significance of Media Didacticsin the Learning Process}

Media didactics is a specialized subsection of general didactics, which has been developing together with the introduction of technical devices to reproduce the curriculum materials stored. Media didactics deals predominantly with the didactic and methodological aspects of development, application, and validation of media technologies in the system of vocational education. Furthermore, the issues of designing and optimizing the learning and teaching process by using media facilities, the required educational conditions, the psychological peculiarities of perception, and, in the center, the technical, organizational, and personal conditions for the use of hardware and software are raised (Schaub and Zenke 2007).

Media didactics, as the didactics' section, deals with the function and influence of media facilities in learning and teaching processes and explores which media facilities are the most suitable for these processes and how to design and to use them 
to activate the learning process for attaining the learning goals (Bendel and Hauske 2004).

Media didactics handles functions and effects of media facilities application in the teaching and learning process. It is intended to select media facilities in the optimum way and to introduce it by taking into account the achievements of academic success and existing context (Merz-Abt 2005).

The media skills, which are acquired by teachers in daily life, more and more benefit as a training capacity and must inevitably be taken into account as educational conditions while planning media resources in the educational process of a higher educational establishment.

\subsection{The Experience in Introduction of Media Didactics}

The analysis of the literature, the challenges in the theory and practice of vocational training in engineering and pedagogy for students and masters by using multimedia tools, and the study of the work experience in this field have enabled us to develop a study guide Media Didactics and to solve successfully a number of problems set in the educational process of the Kyrgyz State Technical University named after Razzakov.

The study guide Media Didactics, which we developed with the use of innovative learning technologies, consists of the following: curriculum, syllabus, teaching materials for practical training, tests, and lecture materials based on the selected materials. In addition, it was complemented with the multimedia products, i.e., animation and interactive programs.

A successful lesson is a lesson that has a constant feedback from trainees. Above all, the possibility of a flexible and rapid redesigning of the training episodes' models is provided by interactive methods and techniques (Astvasaturov 2009a).

The interactive technologies and techniques exist in pedagogics long time ago, when no information and communication technologies in the educational process exist. The modern educational technologies orient us not toward the rapid and forced learning of educational material but for purposeful formation of a system of knowledge, the development of analytical and logical thinking, and professional competence of a specialist.

While implementing the project, we have become convinced that the media didactics is one of the most promising directions in the use of information technologies in education. The application field of the media didactics is very broad, and its potential has not yet been fully explored.

The importance of the use of multimedia technologies in the educational process relates to the further development of informatization and the widespread dissemination of the global computer network Internet.

The necessity for application of multimedia technologies is caused by the transition from the knowledge paradigm of education toward the competency, which 
involves the development of creative capacities of students through interactivity; multimedia in this regard opens immeasurable cognitive capabilities.

This list definitely needs to be complemented with the knowledge and skills in the field of information technologies, which is an integral part of business qualities of a bachelor and a master, but also significantly enhances his/her creative and business activity. Ability to work with text and spreadsheet applications, graphics software, and databases and visualize the results of scientific studies is only part of the requirements for masters. Proficiency in media culture, the ability to make the best use of personal computer and information technologies, to analyze and to synthesize spacetime reality and so on, supports a modern specialist of any profile in proper decision-making.

Currently, the specialized software such as Microsoft Power Point and Macromedia Director considerably has simplified creation of multimedia products. This software allows to:

1. Work with sound, for example, using the Wave Studio software, as well as with audio files, which are created in other specialized software

2. Work with graphic video images, created based on CorelDraw and Photoshop

3. Compose sound, graphics, and video components (Astvasaturov 2009b)

In addition to the above listed media technologies, all we know about open educational resources (OER) in the Internet space, which contributes to the development of students' interest in training and professional advancement, as well as helps them to form images and models, especially in the study of technical objects. Thus, in most cases, the multimedia application has a positive effect on the motivation of students and masters.

While developing the study guide Media Didactics, we used the materials learned in the GIZ and other workshops, such as:

- Development tools OER eXeLearning XHTML editor, iBooks Author, Google Blogger

- Video and audio materials, webinars Articulate, Adobe Acrobat Connect Pro

- Complete e-Learning course or training module Moodle - a specialized system for learning management

- Hot Potatoes - software shell program

Hot Potatoes is a software shell program, which offers teachers the opportunities to create their own interactive tasks without the knowledge of computer programming languages and attracting specialists in the field of programming. Hot Potatoes allows creating interactive learning exercises on the Web based. The peculiarity of this software is the possibility to store the tasks created in a standard Web page format; students need only Web browser (e.g., Internet Explorer) for their use. The software helps to create ten types of exercises in different languages in different disciplines by using text, graphics, audio and video information. Exercises are created by five software blocks (each block can be considered as a stand-alone software): 
1. JQuiz - Quiz - questions with multiple choice answers (four types of tasks). A teacher has the opportunity to make comments for each answer

2. JCloze - Filling the gaps

3. JMatch - Match making (three types of tasks)

4. JCross - Crossword

5. JMix - Sequence recovery

All exercises are performed in the training mode (testing mode is only available for questions with multiple choice answers). The result of the tasks is assessed in percentage. Unsuccessful attempts result in reduction of points. The sixth version of the software contains additional block Masher (tools) that allows combining exercises and other training materials into a thematic block, lessons, and training courses.

\subsection{Conclusion}

The existing multimedia courses and educational software products allow already today to design a training session in a new way. An integrated approach to the use of multimedia technologies in the study of a relatively closed section of the curriculum (with reasonably stable content and well-established teaching methods) of a higher educational institution in the context of audience by using an interactive whiteboard can become a promising and important approach.

As noted above, the multimedia technologies immeasurably expand opportunities for arranging and managing training activities and allow practically realizing the great potential of promising guidance papers, found in the traditional teaching, which, however, remained non-demanded or could not give the desired effect because of certain objective reasons.

Despite of wider using of multimedia training systems in the teaching and learning processes at all levels and in various forms of education, there is an acute shortage of educational multimedia and software available for public at large. Moreover, multimedia introduction to academic subjects and disciplines of the secondary and higher schools is limited both by technical capabilities and conceptualmethodological frameworks.

The aim of our study was to contribute to at least partial liquidation of the existing knowledge gap in the course Media Didactics. The long-term observations of experts resulted in conclusions that a new pedagogical idea in the mass teaching practice is usually more successfully studied and promoted on the theoretical and methodological levels, but its immediate implementation stage (the process of technology mastering) is delayed for various reasons.

Accordingly, the study guide Media Didactics facilitates to improve training of masters of vocational education in the teaching and learning process of the technical higher educational institutions. 


\section{References}

Astvasaturov, G. O. (2009a). Mediadidaktika i sovremennyi urok: Technolog-icheskie priemy. 111 Volgograd: Izdatelstvo "Uchitel". Available online at http://www.labirint.ru/books/442913/. Checked on 30 Dec 2016.

Astvasaturov, G. O. (2009b). Metodika. Technologicheskie priemy. Fragmenty urokov. Volgograd. Izdatelstvo "Uchitel". Available online at http://www.labirint.ru/books/442913/. Checked on 30 Dec 2016.

Bendel, O., \& Hauske, S. (2004). E-Learning. Das Wörterbuch. 1. Aufl. Oberentfel-den/Aarau: Sauerländer.

Fedorov, A. V. (2012). Novye standarty - realnaia vozmojnost dlia media-pedagogiki.Taganrog. Available online at http://mediaeducation.ucoz.ru/_ld/8/876 Alma_Mater_2.pdf. Checked on 5 Jan 2017.

Hutorskyi, A. V., Kraevskyi, V. V. (2007). Osnovy obuchenia: didaktika i metodika.Uchebnoe posobie dlia studentov vyshyh uchebnyh zavedenyi (p. 352). Moskva: Izdatelckyi centr "Akademia". Available online at http://pk15.mskobr.ru/files/v_v_kraevskij_osnovy_obucheniya-_didaktika_i_metodika.pdf. Checked on 30 Dec 2016.

Konovalova, N. A. (2004). Razvitie mediakultury studentov pedagogicheskogo vuza. Vologda.

Merz-Abt, T. (2005). Medienbildung in der Volksschule. Grundlagen und konkrete Umsetzung. Zugl.: Zürich: Univ., Diss., 2004. Zürich: Verl. Pestalozzianum.

Onkovich, A. V. (2012). Mediadidaktika: massmedia v uchebnom processe po russkomu iazyku kak inostrannomu. Riazan.

Schaub, H., \& Zenke, K. G. (2007). Wörterbuch Pädagogik. Orig.-Ausg., grundlegend über-arb., aktualisierte und erw. Neuausg. München: Dt. Taschenbuch-Verl. (dtv, 34346).

Open Access This chapter is licensed under the terms of the Creative Commons Attribution 4.0 International License (http://creativecommons.org/licenses/by/4.0/), which permits use, sharing, adaptation, distribution and reproduction in any medium or format, as long as you give appropriate credit to the original author(s) and the source, provide a link to the Creative Commons license and indicate if changes were made.

The images or other third party material in this chapter are included in the chapter's Creative Commons license, unless indicated otherwise in a credit line to the material. If material is not included in the book's Creative Commons license and your intended use is not permitted by statutory regulation or exceeds the permitted use, you will need to obtain permission directly from the copyright holder.

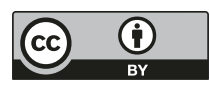

